\title{
Electronic Information Resources Usage of Afghan International University Students in Malaysia
}

\author{
Hanifa Khawari \\ Department of Curriculum and Pedagogy, \\ Faculty of Education Universiti Kebangsaan Malaysia \\ Selangor, Malaysia \\ hanif.1364@gmail.com
}

\author{
Mohd Isa Hamzah, Mohd Hanafi Mohd Yasin \\ Department of Education and Community Wellbeing, \\ Faculty of Education, Universiti Kebangsaan Malaysia, \\ Selangor, Malaysia \\ isa_hamzah@ukm.edu.my, mhmy6365@ukm.edu.my
}

\author{
Hamsi Mansur \\ Department of Educational Technology \\ Faculty of Teacher Training and Education \\ Universitas Lambung Mangkurat \\ Banjarmasin, Indonesia \\ hamsimansur@ulm.ac.id
}

\begin{abstract}
Electronic information resources (EIRs) play an important role in learning process at university level by providing information resources regardless of time and place. The objective of this study is investigating the electronic information resources usage of Afghan international university students in Malaysia. Data was collected through an online survey from 117 Afghan international university students and was analyzed using descriptive analysis using SPSS version 23. This study found the frequency of EIRs usage among Afghan international university students is quite low. The implication of the study is that Malaysian universities should provide fast access to the internet and increase computer availability in their libraries, also provide compulsory and long term EIRs training programs in order to increase EIRs usage among international students.
\end{abstract}

Keywords- Electronic information resources, international students, learning, computer

\section{INTRODUCTION}

The objective of university library as an integral part of the higher learning institutions is to provide information resources for enhancing teaching, learning and research processes [1]. Since1990s, Internet technology, and the World Wide Web revolutionized the information resources access and university libraries operations around the world [2]. University libraries evolved from the days of closed stacks, through shelf browsing and card catalogues punched cards and OPACS to the concept of open access and institutional repositories [3]. This historical migration brought usefulness and ease of accessibility to information for university library users. Electronic information resources are e-journals, e-books, full-text databases, indexing and abstracting databases, reference databases (biographies, dictionaries, directories, and encyclopedias), numeric and statistical databases, e-images, e-audio/ visual resources which are accessible by a computer, or a peripheral device connected directly to the computer such as CD-Rom drive or remotely through network such as the internet.
The benefits of Electronic information resources (EIRs) are: providing information resources regardless of time and place, enabling innovation in teaching, increasing discoveries and creating new fields of enquiry [4], increasing computerliterate students and promote students to keep themselves upto-date in their fields [5], multiple users at the same time, and decreasing the time spent searching for information.

Now in Malaysian university, libraries provide EIRs to fulfil the information needs of their local and international students. Malaysia is known as a centre of educational excellence in the region, and the Malaysian international education sector experienced dramatic growth in the past decade [6]. Over the past two decades, most Malaysian universities have expanded the international activities in volume, scope, and complexity. The Malaysian institutions are making huge efforts to provide quality education [7].

EIRs is becoming an integral part of higher education learning and research and have a positive influence on the academic performance of students. Over the last decade, increased enrolment of international students in colleges and universities of foreign countries has resulted in an increased interest in the research of information needs of international university students based on their different culturaleducational background from the local university students [7]. There is a lack of research about EIRs usage among Afghan international university students in Malaysia who may be using EIRs for the first time. To support their transition and learning in this dynamic context, it is important to understand their experiences in EIRs use, the frequency of EIRs use, the purpose of EIRs use, English and EIRs competency, and challenges toward EIRs use. In order to fill this gap, this study investigates EIRs use, the frequency of EIRs use, the purpose of EIRs use, English and EIRs competency, and challenges toward EIRs use among Afghan international university students in Malaysia. Therefore, this study investigates the 
frequency of electronic information resources use among Afghan international university students in Malaysia

\section{LITERATURE REVIEW}

University libraries provide EIRs in their libraries to their local and international students [2]. EIRs such as digital libraries, online journal, e-journals, e-books, e-learning tutors, online tests, e-discussions, e-news, magazine, e-mail and data archives can be accessed through computers and the Internet [8]. EIRs bring the numerous benefits to the users which include: provision of timely, current, remote, and global access to information [9]. International students need to access EIRs for educational and personal success, and university libraries are the main places for studying and obtaining academic services and resources [10].

Literatures on usage of EIRs among Asian international students in the United States, UK, Australia, New Zealand and Malaysia [7] [11] [12] [13] [14] shows they come from different social, educational and library backgrounds and these kinds of differences influence their adjustment to new academic libraries. Based on studies [7] [11] [12] [13] [14] international students have greater difficulties in using academic libraries compare with their host counterparts in United States, UK, Australia, New Zealand, and Malaysia [7] [11] [12] [13][14]

The familiarity of international students with academic EIRs like journal databases is generally low, and they need to learn information literacy skills [11] [13] A few may even lack the basic skills, and an even greater number of them may even lack the more relevant and timely electronic information skills. For many of these students, their home countries library usage is often limited to instructor-centred and text-based learning approaches hence are not as dynamic and flexible [13]. International university students may avoid using information technology simply because they are unfamiliar with the format and reluctant to ask for help [11]. International students may be accustomed to using the older card catalogue systems in their home countries. Upon their arrival in advanced technological, academic environments, they must learn to use the online catalogue, since the card catalogue is no longer available in most advanced technological academic libraries.

There is a huge gap between outdate handwriting books and EIRs in terms of computing expertise, subject knowledge, culture, language, and age [11] and challenges when using EIRs cause feelings of confusion, anxiety or frustration [13]. Even though some literature exists on international students' EIRs use in Malaysia [7][14] [16] but there is not yet any study about EIRs usage among Afghan international university students in Malaysia. Reference [17] conducted research about academic and cultural adaptation of Afghan international university students in Malaysia, but his study did not focus on technology usage among Afghan international university students. He emphasized how Afghan students, for the most part, generally inform themselves about Malaysian culture and society before their arrival in Malaysia through the internet. In Malaysia, they use social media like Facebook, Skype and instant messaging applications (WhatsApp and Viber) to communicate with close relatives and colleagues.
According to reference [18], "resources are not available for the purchase of indispensable pedagogical inputs such as internet access, textbooks, journals, and lab materials". Probably, some of the Afghan international university students in Malaysian universities come from an academic and cultural environment that is severely lacking in technology and are mostly still using fully print-based libraries. Reference [19] confirm "as there is no internet, the Kabul Public Library does not provide any online library service. Instead, visitors are supposed to use the card catalogue system". Fully Print-based libraries require huge infrastructural support and space to manage growth with limited storage and space and geographical limitations being common challenges for storing information resources. Searching in print-based libraries is also time consuming [20].

EIRs represent an increasingly important component of the collection building activities of libraries. EIRs may also refer to those materials that require computer access. Some of the most frequently encountered types of EIR are e-journals, e-books, full-text databases, indexing and abstracting databases, reference databases (biographies, dictionaries, directories, encyclopaedias, etc.), numeric and statistical databases, eimages, e-audio/ visual resources [21]. EIRs can also be purchased through a variety of methods of payment/methods, such as through university subscription, or through open-access databases which are often fully free. More sophisticated data repositories offer both printed and digital formats of the same material.

Timely and sufficient information is an undeniable element in an international educational and personal development. Libraries through university academic culture provide academic refuge for international students to study and obtain academic resources [10]. Especially since these international students are outside of their comfort zone, libraries benefit by promoting itself as places of not only quiet individual reading but also quiet socializing.

References [13] study 25 international students use of EIRs selected from 2 Australian universities, found many of the internet tools they used were search engines Google or Yahoo, as well as email, Google Translation, and online chat services such as MSN. Not only do these chat services are wasted opportunity in some of these cases, but it is also a huge security risk as malware and viruses are known to take advantage of IM streams. These chat services are essentially huge security risks, for library computers and personal computers/laptops that owned by students.

There are popular tools among international students such as Google, Google Scholar and Wikipedia. Reference[12] in their study at Sheffield Hallam University, found a high usage of Google, and further low use Wikipedia. In the study, almost no one used Google Scholar or databases. There is too much reliance on popular online tools, which is often not considered specialized scholarly material and is subjective as a valid source of information and is only advantageous in terms of its high accessibility. Aspasia Togia in his study involving 59 education graduate students in Aristotle University of Thessaloniki, showed low usage of EIRs [22]. Aspasia Togia 
linked this with a low competency in OPAC, electronic journals and abstract.

Another study was done by Gakibayo for 348 students in Mbarara university library [3] concluded that the highest percentage of usage of search engines, this was followed by electronic mail, e-books, CD-ROM databases, electronic journals, electronic document delivery, and scholarly databases. Other studies that also came to similar conclusion on the over reliance of the purely internet tools as sources of information are; who included gender differences in his study, with high usage of Internet, followed by low usage of e-books, e-journals, databases, OPAC, CD-ROM, e-thesis and dissertation [23].

Reference [24] investigated the use and user perception of electronic information resources among 123 students and staff members of Siva Institute of Frontier Technology, India. With regard to the types of EIRs, the students and faculty members use e-journals, e-books, e-prints, e-databases, e-thesis and dissertations in low level. Here it is notable that the highest EIR tool used were e-journals. Another study that noted the highest of e-journals was done by G. Kiran Kumar [25]. The study investigated students of Bangalore Institute of Dental Science and their EIR usage behaviour. E-journals were highest, followed by e-tutorials, e-databases, e-teaching materials, e-books, subject gateways/ e-portals, e- conference proceedings and lastly, e- thesis and dissertations.

Interestingly in an investigation of the use of EIRs among students of Tirupati universities, found high percentages of ejournals usage that were slightly lower compared to subject specific information websites, international/ regional institution websites [25]. The study also included CD-ROMS which are not universally used in many developed university libraries nowadays. The high level usage of e-books, CD-ROM databases and low usage of research project sites, professional association websites, online bibliographic databases, email, web, CD- ROM, professional groups and IRC reported in this study.

\section{METHOD}

This is a fully quantitative study and explanatory research that uses a questionnaire-based survey to solicit demographic information about respondents with their information needs, EIRs usage, technology literacy, and challenges toward technology usage in particular online information resources.

The population for this study was Afghan international university students in bachelor degree who were supported by Afghan Government's Scholarship. Currently, the number of Afghan international university students at IIUM and USIM are 157 and 28 respectively. Majority of Afghan international university students in both universities were male students. Also, the majority of the students study in computer science and economics.

The population for this study was 185 students and sample for this study was 120 students. The sample was chosen using simple random sampling. This method ensures an equal and independent chance of selection for every member of the population [26]. In this study, all Afghan international university students in IIUM and USIM have an equal and independent chance of being selected. Samples were selected from a Facebook page of Afghan's students association. Members of the page group were written down in database format (Excel) and numerated from 1 to 185 . Numbers were then written on cards and drawn randomly. The numbers drawn were compared against the name list sheet and highlighted. After determining the sample size, the researcher sent the link of the questionnaire through their Facebook accounts.

The data was collected by using an online questionnaire survey mail in the 2016 academic year. The questionnaire instrument consisted of two parts. Part I was designed to identify the demographic characteristics of the respondents. It contained demographic items such as gender, the field of study, length of stay in Malaysia, computer and internet access, computer and internet training, years of computer experience, and frequency of using technology. The questions in part II made based on the study [27]. Part II consisted of three subsections, as follows: frequency of using electronic library resources, the frequency of using search engines and frequency of using online databases. Also some items in Part II developed by the researcher.

Items on the frequency of electronic information resources use, and purpose of electronic information resources use modified based on [27]. Yi measured 11 library services [27], in this study six dependent variables on frequency of using information resources were used: 1) Online Database, 2) Library Catalogue, 3) e-Journal Portal, 4) Thesis (Online Resources), 5) EndNote Software, 6) Interlibrary loan which four of them (Library Catalogue instead of TWU online catalogue, Online Database instead of Databases, e-Journal Portal instead of E-journals to suit the study) used from [27] and an additional 2 for this study. Yi measured ten search engines but in this study, three items (Google, Yahoo and AskJeeves changed to Ask as simplification) chosen based on his study and two search engines (Google Scholar and Bing) added for this study due its popularity, so five dependent variables on frequency of using search engines are: 1) Google, 2) Google Scholar, 3) Yahoo, 4) Ask, 5) Bing [26]. Yi measured 37 items on frequency of online databases but for this study [27], the decision was made to measure 10 dependent variables on frequency of using online resources which only one of them (Emerald) was similar to reference [27] and the rest added based on the most popular and available online databases in Malaysian universities. These are: 1) Science Direct, 2) ProQuest, 3) Emerald, 4) SCOPUS, 5) Sage e-Journals, 6) Springer, 7) Taylor and Francis, 8) Wiley, 9) IEEE Explore, 10) Oxford University Press Journals.

This question is organized into a five-point Likert scale in which each scale has different statements. Respondents are asked to indicate their responses ranging from "no use", "a few times a month", "a few times a week", "once a week" or "every day" with each statement. Students are required to click on checkboxes inside each column of "no use", "a few times a month", "a few times a week", "once a week" or "every day". Clicking on the checkboxes will produce a full bullet $(\bullet)$ inside it. Scoring the students' answer is done by attributing values to the responses, 1 to 5 , respectively, and by assigning a low or high usage direction to the statement to evaluate the response. 
Total sub scores are compiled by adding the scores of the five statements for each subscale. For example, a response range of "every day" for the statement will receive a score of 5. On the other hand, a response range of "no use" for this statement will receive a score of 1 . A "low" or "high" usage direction was also assigned to the statement for evaluating the response.

\section{RESULTS AND DISCUSSION}

The data in terms of respondents' profile were analyzed based on the descriptive statistics analysis involving frequency and percentages. Table I shows the background of the respondents totaling 117 .

TABLE I. RESPONDENTS'PROFILE

\begin{tabular}{|c|c|c|c|}
\hline \multicolumn{2}{|c|}{ Respondents' Profile } & Frequency & Percentage \\
\hline \multirow{2}{*}{ Gender } & Male & 102 & 87.2 \\
\hline & Female & 15 & 12.8 \\
\hline \multirow{3}{*}{ Technology access } & Computer desktop & 16 & 13.7 \\
\hline & Laptop & 111 & 94.9 \\
\hline & Internet & 117 & 100.0 \\
\hline \multirow{4}{*}{$\begin{array}{l}\text { Frequency of } \\
\text { technology use }\end{array}$} & $\begin{array}{l}\text { Less than once a } \\
\text { month }\end{array}$ & 1 & 0.9 \\
\hline & $\begin{array}{l}\text { Between once a } \\
\text { week and once a } \\
\text { month }\end{array}$ & 0 & 0 \\
\hline & $\begin{array}{l}\text { A few times each } \\
\text { week }\end{array}$ & 1 & 0.9 \\
\hline & Almost every day & 115 & 98.3 \\
\hline \multirow{4}{*}{$\begin{array}{c}\text { Years of } \\
\text { technology } \\
\text { experiences }\end{array}$} & $1-2$ years & 1 & 0.9 \\
\hline & $2-3$ years & 11 & 9.4 \\
\hline & $3-4$ years & 21 & 17.9 \\
\hline & Above 4 years & 84 & 71.8 \\
\hline \multirow{4}{*}{$\begin{array}{c}\text { Types of } \\
\text { technology training }\end{array}$} & Formal training & 42 & 35.9 \\
\hline & Friends & 15 & 12.8 \\
\hline & Family & 4 & 3.4 \\
\hline & Self- taught & 56 & 4.79 \\
\hline
\end{tabular}

Table I shows percentages of respondents based on their gender (102 male and 15 female); technology access (94.9\% Laptop and the rest Desktop Computer); frequency of technology usage $(98.3 \%$ almost every day); years of technology experiences $(71.8 \%$ above 4 years, $17.9 \%$ for $3-4$ years, 9.4\% between 2-3 years and only $0.9 \%$ between $1-2$ years); and types of technology training (47.9\% through Selftaught, 35.9\% through Formal training, 12.8\% through Friends and only $3.4 \%$ through Family).

Table II shows the frequency of the use of Information Resources.

TABLE II. RESPONDENTS' FREQUENCY OF INFORMATION RESOURCES

\begin{tabular}{|c|c|c|c|c|c|c|c|}
\hline $\begin{array}{l}\text { Information } \\
\text { resources }\end{array}$ & $\begin{array}{l}\text { No } \\
\text { Use } \\
(\%)\end{array}$ & $\begin{array}{c}\text { Afew } \\
\text { times } \\
a \\
\text { month } \\
(\%)\end{array}$ & $\begin{array}{c}A \\
\text { few } \\
\text { times } \\
\text { a } \\
\text { week } \\
(\%)\end{array}$ & $\begin{array}{c}\text { Once } \\
\text { a } \\
\text { week } \\
(\%)\end{array}$ & $\begin{array}{c}\text { Every } \\
\text { day } \\
(\%)\end{array}$ & $M$ & $S D$ \\
\hline $\begin{array}{c}\text { Library } \\
\text { Catalogue } \\
\text { Website }\end{array}$ & 11.1 & 41.0 & 23.1 & 12.8 & 12.0 & 2.73 & 1.18 \\
\hline e-Journals & 24.8 & 32.5 & 20.5 & 16.2 & 6.0 & 2.69 & 1.14 \\
\hline $\begin{array}{l}\text { EndNote } \\
\text { Software }\end{array}$ & 35.9 & 21.4 & 17.1 & 16.2 & 9.4 & 2.46 & 1.20 \\
\hline
\end{tabular}

\begin{tabular}{|c|c|c|c|c|c|c|c|}
\hline $\begin{array}{c}\text { Information } \\
\text { resources }\end{array}$ & $\begin{array}{l}\text { No } \\
\text { Use } \\
(\%)\end{array}$ & $\begin{array}{c}\text { Afew } \\
\text { times } \\
a \\
\text { month } \\
(\%)\end{array}$ & $\begin{array}{c}A \\
\text { few } \\
\text { times } \\
a \\
\text { week } \\
(\%)\end{array}$ & $\begin{array}{c}\text { Once } \\
\text { a } \\
\text { week } \\
(\%)\end{array}$ & $\begin{array}{c}\text { Every } \\
\text { day } \\
(\%)\end{array}$ & $M$ & $S D$ \\
\hline $\begin{array}{c}\text { Library } \\
\text { Online } \\
\text { databases }\end{array}$ & 12.0 & 39.3 & 26.5 & 12.0 & 10.3 & 2.58 & 1.26 \\
\hline E-Thesis & 25.6 & 23.1 & 27.4 & 15.4 & 8.5 & 2.41 & 1.36 \\
\hline $\begin{array}{c}\text { Interlibrary } \\
\text { loan }\end{array}$ & 29.1 & 31.6 & 16.2 & 13.7 & 9.4 & 2.42 & 1.29 \\
\hline \multicolumn{6}{|c|}{ Average } & 2.54 & 1.23 \\
\hline
\end{tabular}

Table II shows the results of how often Afghan international university students use library and information resources to meet their information needs. All mean scores are smaller than 3. It means, in general, Afghan international university students are not using library and information resources to meet their information needs. Based on Table 2, the level of usage of library and information resources among Afghan international university students is quite low $(\mathrm{M}=$ 2.54).

Table III shows the frequency of search engines usage among the students:

TABLE III. RESPONDENTS' FREQUENCY OF SEARCH ENGINES USAGE

\begin{tabular}{|c|l|l|l|l|l|l|l|}
\hline $\begin{array}{c}\text { Search } \\
\text { Engines }\end{array}$ & $\begin{array}{c}\text { No } \\
\text { Use } \\
(\%)\end{array}$ & $\begin{array}{c}\text { A few } \\
\text { times a } \\
\text { month } \\
(\%)\end{array}$ & $\begin{array}{c}\text { A few } \\
\text { times } \\
\mathbf{a} \\
\text { week } \\
(\%)\end{array}$ & $\begin{array}{c}\text { Once } \\
\mathbf{a} \\
\text { week } \\
(\%)\end{array}$ & $\begin{array}{c}\text { Every } \\
\text { day } \\
(\%)\end{array}$ & $M$ & $S D$ \\
\hline Google & 1.7 & 7.7 & 14.5 & 7.7 & 68.4 & 4.3 & 1.1 \\
\hline $\begin{array}{c}\text { Google } \\
\text { Scholar }\end{array}$ & 12.8 & 31.6 & 21.4 & 16.2 & 17.9 & 2.9 & 1.3 \\
\hline Yahoo & 22.2 & 31.6 & 23.9 & 9.4 & 2.8 & 2.6 & 1.3 \\
\hline Ask & 51.3 & 24.8 & 14.5 & 4.3 & 5.1 & 1.9 & 1.1 \\
\hline Bing & 59.8 & 18.8 & 4.3 & 12.0 & 5.1 & 1.8 & 1.2 \\
\hline & \multicolumn{7}{|c|}{ Average } \\
\hline
\end{tabular}

In addressing the frequency of search engines, five items were measured. Table III shows the results of how often Afghan international university students used search engines to meet their information needs. All mean scores except Google, are smaller than 3. In terms of varied use of search engines as an information search strategy, Afghan international university students are not efficient and proactive enough in their usage of search engines Google with a mean score of 4.33 , shows that, apart from Google's higher relative popularity, is perhaps the only preferred search engine among Afghan international university students. Table 3 also shows the level of usage of search engines among Afghan international university students is low $(\mathrm{M}=2.71)$.

Table IV below shows the frequency of online database usage among Afghan's students. 
TABLE IV. ThE FREQUENCY OF ONLINE DATABASES USAGE

\begin{tabular}{|c|c|c|c|c|c|c|c|}
\hline $\begin{array}{c}\text { Online } \\
\text { Databases }\end{array}$ & $\begin{array}{l}\text { No } \\
\text { Use } \\
(\%)\end{array}$ & $\begin{array}{c}\text { Few } \\
\text { times } \\
\text { a } \\
\text { month } \\
(\%) \\
\end{array}$ & $\begin{array}{c}\text { Few } \\
\text { times } \\
\text { a } \\
\text { week } \\
(\%) \\
\end{array}$ & $\begin{array}{l}\text { Once } \\
\text { a } \\
\text { week } \\
(\%)\end{array}$ & $\begin{array}{c}\text { Every } \\
\text { day } \\
(\%)\end{array}$ & $M$ & $S D$ \\
\hline Science Direct & 31.6 & 35.9 & 15.4 & 10.3 & 6.8 & 2.24 & 1.20 \\
\hline ProQuest & 53.0 & 24.8 & 9.4 & 8.5 & 4.3 & 1.83 & 1.15 \\
\hline Emerald & 59.0 & 23.9 & 9.4 & 3.4 & 4.3 & 1.70 & 1.06 \\
\hline SCOPUS & 53.8 & 21.4 & 17.1 & 4.3 & 3.4 & 1.82 & 1.07 \\
\hline $\begin{array}{c}\text { Sage e- } \\
\text { Journals }\end{array}$ & 50.4 & 28.2 & 15.4 & 2.6 & 3.4 & 1.80 & 1.01 \\
\hline Springer & 52.1 & 26.5 & 11.1 & 6.0 & 4.3 & 1.83 & 1.11 \\
\hline $\begin{array}{c}\text { Taylor and } \\
\text { Francis }\end{array}$ & 56.4 & 25.6 & 8.5 & 5.1 & 4.3 & 1.75 & 1.08 \\
\hline Wiley & 55.6 & 23.9 & 12.0 & 5.1 & 3.4 & 1.76 & 1.06 \\
\hline IEEE Explore & 39.3 & 34.2 & 12.8 & 7.7 & 6.0 & 2.06 & 1.17 \\
\hline $\begin{array}{c}\text { Oxford } \\
\text { University } \\
\text { Press Journals }\end{array}$ & 29.9 & 35.0 & 17.9 & 12.8 & 4.3 & 2.26 & 1.14 \\
\hline \multicolumn{6}{|c|}{ Average } & 1.90 & 1.10 \\
\hline
\end{tabular}

Table IV shows the results of Afghan's students use these online databases in order to meet their information needs. All mean scores are smaller than 2. This is the lowest average of all 3 categories, indicating a high lack of usage of online databases among Afghan international university students to meet their information needs. Table IV also shows the level of online databases usage among Afghan international university students is very low $(M=1.90)$.

Table $\mathrm{V}$ shows the conclusion of EIRs usage among Afghan's students.

TABLE V. ELECTRONIC INFORMATION RESOURCES USE $(\mathrm{N}=117)$

\begin{tabular}{|c|l|l|}
\hline Constructs & \multicolumn{1}{|c|}{$\boldsymbol{M}$} & $\boldsymbol{S D}$ \\
\hline Information Resources & 2.54 & 1.23 \\
\hline Search Engines & 2.71 & 1.21 \\
\hline Online Databases & 1.90 & 1.10 \\
\hline
\end{tabular}

The frequency of usage of all library and information resources, search engines and online databases is quite low among Afghan international university students, with the online databases being the lowest. The study examined the frequency of electronic information resources use (search engines, information resources and online databases) among Afghan international university students in Malaysian universities. A descriptive study showed that the usage of electronic information resources was low among Afghan international university students. Specifically, the mean scores for search engines $(M=2.71)$, information resources $(M=2.54)$ and online databases $(\mathrm{M}=1.90)$ did not meet the criterion value of 3.00. Among search engines, Google usage was high among Afghan international university students with the mean score of 4.33 .

\section{CONCLUSION}

The use of electronic information sources among international students is low. However, this study found that even though the use of EIRs was low, surprisingly, students often used Google search in their work. This study has several implications for universities and university libraries in Malaysia. In order to support international students to use EIRs, universities need to implement strategies that ensure effective, successful experiences for international students to use EIRs for solving academic problems. Curriculum board of Malaysian universities should ensure that EIRs instruction is made a compulsory course with two credit load for all international students during the first and second semesters of their first year in the university. It is necessary because EIRs skills is a prerequisite requirement for effective use of EIRs. Also, there are rooms of improvement to make sure all students have access to fast speed internet inside universities and hostels, which should be achieved through improvement of computer network infrastructure. Free and easy access to the internet and EIRs will enable university students to use EIRs more frequent. In addition, university libraries should develop training programs for the students library services (e.g library process, library departments, and sections, available technologies in library, borrowing books, open access database, pay per view journals, availability of online guidance and specialized instruction) in multiple ways (eg. Facebook, Twitter, brochures, boards). Also, university libraries in Malaysia should provide fast and responsive technical staff for assisting in multiple ways (e.g. Face to face, Telegram, WhatsApp) to international students.

\section{REFERENCES}

[1] W. a. K. W. Dollah, Digital Reference Services in Academic Libraries, Kuala Lumpur: University of Malaya Press, 2012.

[2] A. B. A. Bakar, and P. N. L. Jaafar, "Sustainability through website development: The case of public libraries in Malaysia" Qualitative and Quantitative Methods in Libraries, vol. 2, no. 1, pp. 87-92, 2017.

[3] J. R. I. O. G. Anna, Electronic Information Resources Utilization by Students in Mbarara University Library Library Philosophy and Practice 29, 2013.

[4] T. Nazir, "Use and Adequacy of E-resources by the Research Scholars and Students of the University of Kashmir in Science \& Social Science Faculties: A Case Study," Brazilian Journal of Information Science: Research Trends, vol. 9, no. 1, 2015.

[5] D. Kumar, Use and Awareness of Electronic Information Resources and Services among the Teachers and Students of Institute of Informatics and Management Sciences (Iims) Meerut, U. P. (India): A Case Study. International Journal of Information Library \& Society vol. 1, no. 1,2012 .

[6] S. Malaklolunthu and P. S. Selan, "Adjustment problems among international students in Malaysian private higher education institutions," Procedia - Social and Behavioral Sciences, vol. 15, pp. 833-837, 2011.

[7] D. S. H. Safahieh, Information Needs and Information Seeking Behavior of International Students in Malaysia. Proceedings of the Asia- Pacific Conference on Library \& Information Education \& Practice, 2006.

[8] N. Sivathaasan, K. Murugathas, and K. Chandrasekar, "Attitude towards the usage of electronic information resources in Medical Library, University of Jaffna, Sri Lanka," Information and Knowledge Management, vol. 4, no. 1, pp. 86-93. 2014

[9] N. B. Ukachi, "Students' Attitudes as a Determining Factor to Electronic Information Resources Use in University Libraries in SouthWest, Nigeria," DESIDOC Journal of Library \& Information Technology, vol. 34, no. 4, pp. 9, 2014.

[10] B. Mehra, and D. Bilal, "International students' information needs and use of technology," Proceedings of the American Society for Information Science and Technology, vol. 44, no. 1, pp. 1-8. 2008. 
[11] A. S. Abdullah, Factors affecting international students use of the online catalog and other information sources, 2000.

[12] L. Bullingham and A. E. Lahlafi, “'Library shock' - the expectations and realities of library and research skills for international students," Student Engagement and Experience Journal, vol. 1, no. 3, Dec. 2012.

[13] H. Hughes, "International Students' Experiences of University Libraries and Librarians," Australian Academic \& Research Libraries, vol. 41, no. 2, pp. 77-89, Jun. 2010

[14] C. Mu, "Marketing academic library resources and information services to international students from Asia," Reference Services Review, vol. 35, no. 4, pp. 571-583, Nov. 2007.

[15] K. Abdoulaye and S. Majid, "Use of the Internet for reference services in Malaysian academic libraries," Online Information Review, vol. 24, no. 5, pp. 381-389, Oct. 2000.

[16] P. G. Ariyapala, and N. N. Edzan, Foreign postgraduate students and the online catalogue at the university of Malaya library. Malaysian Journal of Library \& Information Science, vol.7, no. 1, pp 1-11. 2002.

[17] Azimi, H. 2015. The Academic and Cultural Adaptation Experience of Afghan Students in Malaysia. 121

[18] W. Bank. Afghanistan Country Summary of Higher Education, 2007.

[19] Q. Suroush, Reading in Kabul: The State of Afghan Libraries Afghanistan Analysts Network, 2015.
[20] A. A. Bagudu, and H. Sadiq, Students'perception of digital library services: a case study of international islamic university, Malaysia. 2013.

[21] M. Saravanan, and S. M. Esmail, "Impact of Electronic Information Seeking Behaviour of Users of Selected Engineering Colleges Affiliated to Anna University in Thiruvallur District: A Case Study," Asian Journal of Information Science and Technology, vol. 5, no. 1, pp. 15-22, 2015.

[22] A. Togia and N. Tsigilis, "Awareness and Use of Electronic Information Resources by Education Graduate Students: Preliminary Results from the Aristotle University of Thessaloniki," Qualitative and Quantitative Methods in Libraries, Jan. 2010

[23] M. D. Bassi, and E. Camble, Gender differences in use of electronic resources in University Libraries of Adamawa State, Nigeria, 2011.

[24] V. Chandran, Use and user perception of electronic information resources: A case study of Siva Institute of Frontier Technology, India. Chinese Librarianship: An International Electronic Journal, vol. 36, 2013.

[25] G. K. Kumar, and M. Kumbar, Electronic information resources use patterns by the faculty and students of Bangalore Institute of Dental Sciences, Bengaluru: a study. 2014.

[26] N. E. Wallen, and J. R. Fraenkel, How to design and evaluate research in education, 2006.

[27] Z. Yi, International Student Perceptions of Information Needs and Use The Journal of Academic Librarianship, vol. 33, no. 6, 2007. 